\title{
PENJADWALAN PROYEK DENGAN PENERAPAN SIMULASI MONTE CARLO PADA METODE PROGRAM EVALUATION REVIEW AND TECHNIQUE (PERT)
}

\author{
Widya Nurul Shofa, Irwan Soejanto, Trismi Ristyowati \\ Program Studi Teknik Industri Jurusan Teknik Industri Fakultas Teknik Industri \\ Universitas Pembangunan Nasional "Veteran" Yogyakarta \\ Jl. Babarsari 2 Tambakbayan, Yogyakarta, 55281 \\ Telp. (0274) 485363 Fak : (0274) 486256
}

\begin{abstract}
PT At Taqwa Sejahtera has implemented of residential development that duration about 152 day. Due to delay in the supply of primary raw materials, the processing time getting longer or not accordance to planning schedule on October 27, 2017. The project delay have impact on the company which will given punishment.

The aim of this study research to the evaluate the project implementation schedule and project scheduling for more optimal time, with the best probability, and minimize the influence of the causes of delays to the project completion time. Project scheduling processing is done by using Program Evaluation Review and Technique (PERT) and implementation with Monte Carlo simulation using Ms Excel software.

Based on data processing, the calculation of the project point accelerated time to 147 days with cost $R p$ 417.315.909,25 and probability of 63\%, whereas with the application of Monte Carlo simulus the average conviction rate is at 156 days with cost $R p$ 402,310,654.25 and probability of $94 \%$.
\end{abstract}

Keywords :The residential project, Project scheduling, Evaluation Review and Technique (PERT), Monte Carlo simulation.

\section{PENDAHULUAN}

Pembangunan pada era sekarang merupakan salah satu hal utama untuk menunjang keberlangsungan kehidupan masyarakat. Setiap tahunnya pembangunan selalu dilakukan dari berbagai sektor, dan terus meningkat sebagai pembaharuaan dan penambahan infrastruktur penunjang kebutuhan masyarakat. Salah satu pembangunan infrastruktur yang terus berlangsung dari tahun ketahun yaitu pembangunan sebuah hunian baru, dimana hunian tersebut dibuat dan dirancang sesuai dengan keadaan daerah sekitar. Pada pembangunan Perumahan Griya Amanah Asri II Kendal, Tipe 36/80 di Jl. Halmahera III No. 11 Semarang, salah satu penunjang infrastruktur untuk masyarakat yang menginginkan hunian di daerah tersebut. Pada proses yang telah berjalan selama $26 \%$ terjadi keterlambatan selama 12 hari yang disebabkan oleh terlambatnya pasokan bahan baku utama

\section{Definisi Proyek}

Kegiatan proyek dapat diartikan sebagai satu kegiatan sementara yang berlangsung dalam jangka waktu terbatas, dengan alokasi sumber daya tertentu dan dimaksudkan untuk menghasilkan produk di tempat pembangunan, dan berdampak pada mundurnya jadwal pengerjaan proyek. Apabila keterlambatan tidak ditangani berakibat pada biaya penalty yang harus dikeluarkan kontraktor kepada pemilik perumahan. Untuk itu percepatan waktu penyelesaian dilakukan menggunakan metode Program Evaluation Review and Technique (PERT), metode tersebut digunakan karena berorientasi pada waktu yang mengarah pada penentuan jadwal dan estimasi waktunya yang bersifat probabilistik / tidak pasti, dan penerapan dengan metode Simulai Monte Carlo digunakan untuk mengetahui nilai tingkat keyakinan dari hasil percepatan waktu penjadwalan proyek sebelumnya. Dari hasil ini diharapkan dapat menjadi acuan supaya pengerjaan proyek dapat berjalan sesuai dengan waktu yang telah direncanakan.

(deliverable) yang kriteria mutunya telah digariskan dengan jelas (Soeharto, 2002).

\section{Manajemen Proyek}

Menurut Kerzner (2006) Manajemen proyek adalah merencanakan, mengorganisir, memimpin, dan mengendalikan sumber daya 
perusahaan untuk mencapai sasaran jangka pendek yang telah ditentukan. Lebih jauh, manajemen proyek menggunakan pendekatan sistem dan hierarki (arus kegiatan) vertical maupun horizontal.

\section{Program Evaluation Review and Technique (PERT)}

Menurut Soeharto (2002) PERT

memakai pendekatan yang menganggap bahwa kurun waktu kegiatan tergantung pada banyak faktor dan variasi, sehingga lebih baik perkiraan diberi rentang (range), atau memakai tiga angka estimasi. Metode PERT lebih mengorientasikan pada peristiwa yang terjadi, berbeda dengan CPM yang berorientasi pada kegiatannya. Pada PERT kurun waktu proyek selesai dan waktu proses bersifat tidak pasti (probabilistik).

\section{Slope Biaya}

Slope Biaya menyatakan berapa besar berubahnya biaya bila suatu aktivitas dipercepat atau diperlambat. Kemiringan slope biaya akan bertambah bila aktivitas dipercepat penyelesaiannya dengan ongkos perwaktunya lebih mahal.

\section{TPD dan TDT Proyek}

Titik Proyek Dipersingkat (TPD) atau project crash-point merupakan batas maksimumwaktu proyek dapat dipersingkat.

\section{METODOLOGI PENELITIAN}

Obyek yang digunakan yaitu proyek pembuatan Perumahan Griya Amanah Asri II Kendal, Tipe 36/80 sebanyak 4 (empat) unit di J1. Halmahera III No. 11 Semarang. Durasi proyek direncanakan berlangsung selama 6 (enam) bulan yang dimulai pada 19 April 2017 sampai dengan 27 Oktober 2017. tahap pengerjaan telah berjalan selama 48 hari dengan presentase $26 \%$, dan presentase pembangunan belum terlaksana sebesar $74 \%$. Keterlambatan proyek berada pada pengerjaan konstruksi beton selama 12 hari, dari rencana awal selama 152 hari.

nilai probabilitas dari hasil percepatan waktu tersebut. Langkah-langkah pengolahan data pada penelitian ini adalah sebagai berikut

1. Membuat waktu penyelesaian proyek aktual menggunakan metode Program Evaluation Review and Technique
Pada TPD ini mungkin masih terdapat beberapa kegiatan komponen proyek yang belum dipersingkat waktunya, dan bila ingin dipersingkat juga (berarti mempersingkat waktu semua kegiatan proyek secara teknis dapat dipersingkat), maka akan memiliki total biaya proyek tanpa mengurangi waktu. Titik tersebut dinamakan Titik Dipersingkat Total (TDT) atau all crash-point.

\section{Simulasi Monte Carlo}

Monte Carlo adalah simulasi tipe probabilitas yang mendekati solusi sebuah masalah dengan melakukan sampling dari proses acak. Monte Carlo melibatkan penetapan distribusi probabilitas dari sebuah variable yang dipelajari dan kemudian dilakukan pengambilan sampel acak dari distribusi untuk menghasilkan data. Ketika sistem terdapat elemen-elemen yang memperlihatkan perilaku yang cenderung tidak pasti atau probabilistik maka metode simulai Monte Carlo sapat diterapkan.

\section{Histogram}

Histogram merupakan kumpulan suatu data dan disajikan dalam bentuk tabel dan akan memberikan kemudahan dalam menginterpretasikannya dengan menggunakan data balok dan dapat diketahui bentuk dari suatu distribusi (Arifin, 2009).

\section{Pengamatan pada penelitian ini dilakukan langsung terhadap proyek pembanguunan diperumahan Griya Amanah Asri II Kendal, Semarang seperti data keterkaitan antar kegiatan proyek. serta pengamatan secara tidak langsung atau data telah tersedia di perusahaan seperti rancangan anggaran biaya, dan jadwal perencanaan proyek. \\ Pengolahan data merupakan tahap selanjutnya setelah melakukan pengamatan. Pengolahan data dalam penelitian ini dilakukan untuk menghitung angka percepatan waktu serta}

(PERT). Langkah-langkahnya sebagai berikut.

a. Mengelompokkan tiap-tiap aktivitas sesuai dengan urutan pengerjaannya, banyaknya aktivitas tiap sub pengerjaannya, serta hubungan antar kegiatan 
melalui data rancangan anggaran biaya (RAB) proyek.

b. Membuat jaringan kerja (network planning) berdasarkan waktu aktual proyek.

c. Mencari jalur kritis dengan konsep te, dimana slack $=0$.

d. Mencari nilai standard deviasi, yang hasilnya akan digunakan untuk menghitung waktu optimis dan waktu pesimis.

e. Menghitung nilai waktu optimis.

f. Menghitung nilai waktu pesimis

2. Menghitung waktu percepatan penjadwalan proyek menggunakan metode Program Evaluation Review and Technique (PERT). Langkahlangkahnya sebagai berikut.

a. Menghitung nilai ekspektasi waktu (waktu yang diharapkan).

b. Menentukan nilai variansi.

c. Menghitung lama percepatan waktu.

d. Menghitung nilai slope biaya dari tiap aktivitas berdasarkan percepatan waktu.

e. Mengurutkan nilai slope biaya, dari yang terkecil ke terbesar.

f. Membuat titik proyek dipercepat (TPD) berdasarkan urutan nilai slope biaya.

\section{PEMBAHASAN}

\section{Pengumpulan data}

a. Aktivitas pekerjaan dan hubungannya g. Membuat kurva biaya proyek berdasarkan nilai titik proyek dipercepat (TPD)

h. Menentukan nilai presentase kemungkinan proyek dapat selesai.

3. Melakukan tahapan simulasi Monte Carlo. Adapun langkah-langkahnya sebagai berikut.

a. Menghitung nilai deviasi standar dengan nilai waktu percepatan dan nilai waktu aktual menggunakan bantuan software Microsoft excel.

b. Menghitung nilai rata-rata data dengan nilai waktu percepatan dan nilai waktu aktual menggunakan bantuan software Microsoft excel.

c. Menghitung nilai absolute error.

d. Menentukan jumlah replikasi.

e. Membangkitkan angka bilangan random berdasarkan jumlah replikasi yang telah dihitung menggunakan bantuan software Microsoft Excel.

f. Melakukan pemeriksaan dengan membuat histogram pada data analysis menggunakan bantuan software Microsoft Excel untuk mengetahui nilai probabilitas. Output pemeriksaan berupa grafik tingkat keyakinan.

Berikut merupakan Uraian pekerjaan dan kegiatan pekerjaan proyek dapat dilihat pada Tabel 1.

Tabel 1. Keterkaitan Kegiatan dan Waktu Kegiatan Perencanaan Awal

\begin{tabular}{|l|c|c|}
\hline \multicolumn{1}{|c|}{ Kegiatan } & Hari & $\begin{array}{c}\text { Kegiatan } \\
\text { Sebelumnya }\end{array}$ \\
\hline $\begin{array}{c}\text { A. } \begin{array}{c}\text { Pondasi } \\
\text { Pekerjaan Persiapan }\end{array} \\
\text { 1. Pembersihan Lapangan }\end{array}$ & \\
\hline 2. Pasangan Bowlpank & 4 & - \\
\hline 3. Pengadaan Air Kerja & 1 & - \\
\hline 4. Gudang Semen dan Alat & 7 & 3 \\
\hline Pekerjaan Galian & & \\
\hline 5. Galian Tanah & 7 & 2 \\
\hline 6. Urugan Kembali Galian Tanah & 2 & 9 \\
\hline Pekerjaan Pondasi Batu Kali & & \\
\hline 7. Urugan Pasir Bawah Pondasi & 1 & 5 \\
\hline 8. Pasangan Pondasi Batu Kosong & 3 & 7 \\
\hline
\end{tabular}


Tabel 1. (Lanjutan)

\begin{tabular}{|c|c|c|}
\hline Kegiatan & Hari & $\begin{array}{l}\text { Kegiatan } \\
\text { Sebelumnya }\end{array}$ \\
\hline 9. Pasangan Pondasi Batu Kali (1:3) & 8 & 8 \\
\hline \multicolumn{3}{|l|}{ B. Pekerjaan Beton } \\
\hline 10. Pondasi Plat & 5 & 8,9 \\
\hline 11. Sloof $15 \times 20$ & 3 & 10 \\
\hline 12. Kolom $15 \times 15$ & 7 & 11 \\
\hline 13. Kolom 15 x 20 & 5 & 12 \\
\hline 14. Kolom 20 x 30 & 8 & 13 \\
\hline 15. Balok $15 \times 20$ & 3 & 13 \\
\hline 16. Balok $30 \times 35$ & 8 & 15 \\
\hline 17. Plat Beton & 10 & 15,18 \\
\hline 18. Ring Balok & 4 & 12 \\
\hline 19. Tangga Beton Bertulang & 4 & 20 \\
\hline 20. Beton Cor $1: 2: 3$ & 1 & 14,16 \\
\hline \multicolumn{3}{|l|}{ C. $\quad$ Pekerjaan Dinding } \\
\hline 21. Pasangan Dinding Batu Bata (1:4) & 34 & 13 \\
\hline 22. Pasangan Dinding Batu Bata (1:2) & 5 & 21 \\
\hline 23. Pasangan Kusen Pintu dan Jendela & 6 & 12 \\
\hline \multicolumn{3}{|l|}{ D. Pekerjaan Kap dan Atap } \\
\hline 24. Pekerjaan Balok Dinding 8/12 & 2 & 19 \\
\hline 25. Pekerjaan Kuda-Kuda kayu & 4 & 24 \\
\hline 26. Pekerjaan Rangka Atap & 7 & 21 \\
\hline 27. Papan Liplank $3 / 25$ & 3 & 30 \\
\hline 28. Pekerjaan Papan reuter $3 / 25$ & 3 & 27 \\
\hline 29. Pemasangan Gording Nog $8 / 12$ & 14 & 36 \\
\hline 30. Pemasangan Talang & 2 & 32 \\
\hline 31. Pemasangan Atap & 4 & 26,22 \\
\hline 32. Pemasangan Perabung & 1 & 31 \\
\hline \multicolumn{3}{|l|}{ E. Pekerjaan Plafon } \\
\hline 33. Rangka Plafon & 12 & 30 \\
\hline 34. Plafond Gypsum & 17 & 28,33 \\
\hline 35. Memasang Lis Plafond & 2 & 34 \\
\hline \multicolumn{3}{|l|}{ F. $\quad$ Pekerjaan Plasteran } \\
\hline 36. Plasteran Dinding (1:2) & 6 & 24 \\
\hline 37. Plasteran Dinding (1:4) & 40 & 25 \\
\hline 38. Pasangan Dinding dan Porslin & 6 & 37 \\
\hline 39. Acian & 12 & 38 \\
\hline \multicolumn{3}{|l|}{ G. Pekerjaan Lantai } \\
\hline 40. Urugan Pasir & 1 & 29 \\
\hline 41. Pasangan Lantai Kramik 40 x 40 & 29 & 40 \\
\hline 42. Pasangan Lantai Kramik $20 \times 20$ & 2 & 41 \\
\hline
\end{tabular}

Tabel 1. (Lanjutan)

\begin{tabular}{|c|c|c|}
\hline \multicolumn{1}{|c|}{ Kegiatan } & Hari & $\begin{array}{c}\text { Kegiatan } \\
\text { Sebelumnya }\end{array}$ \\
\hline H. Pekerjaan Pintu dan Jendela & & \\
\hline 43. Pintu & 22 & 41 \\
\hline 44. Jendela Kaca & 22 & 41 \\
\hline 45. Kaca Tebal 5 MM & 1 & 47 \\
\hline 46. Pasangan Engsel Pintu & 5 & 33 \\
\hline 47. Pasangan Kunci Tanam Antik & 2 & 67 \\
\hline
\end{tabular}




\begin{tabular}{|c|c|c|}
\hline I. Pekerjaan Pengecatan & & \\
\hline 48. Mendempul dan Menggosok Kayu & 1 & 17 \\
\hline 49. Mengecat Kayu Baru & 8 & 48 \\
\hline 50. Mengecat Tembok Baru & 6 & 34 \\
\hline 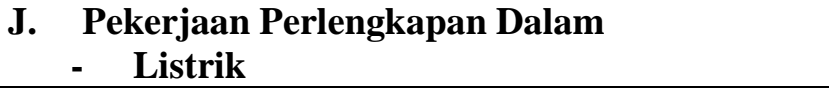 & & \\
\hline 51. Pasangan Lampu Pijar & 2 & 55 \\
\hline 52. Pemasangan Stop Kontak & 1 & 55 \\
\hline 53. Pemasangan Lampu TL & 1 & 52 \\
\hline 54. Pemasangan MCB & 1 & 53 \\
\hline 55. Pemasangan kabel Jaringan & 4 & 31 \\
\hline 56. Pitting Lampu & 2 & 55 \\
\hline 57. Pemasangan Sakelar & 2 & 56 \\
\hline - $\quad$ Sanitasi dan Instalasi Air & & \\
\hline 58. Pemasangan Kloset Jongkok & 1 & 60 \\
\hline 59. Pemasangan Kloset Duduk & 2 & 60 \\
\hline 60. Pemasangan Floor Draine & 1 & 57,63 \\
\hline 61. Bak Cuci Piring & 1 & 58 \\
\hline 62. Pemasangan Wastafel & 1 & 58 \\
\hline 63. Pemasangan Pem. Pipa Air Ø 3" Per M' & 1 & 54 \\
\hline 64. Pemasangan Pipa Air Ø 3/4" AW Per M' & 1 & 54 \\
\hline 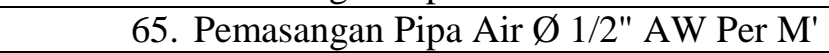 & 1 & 54 \\
\hline 66. Pemasangan Kran Air Ø 3/4" atau 1/2" & 1 & 54 \\
\hline K. Pekerjaan Perlengkapan Luar & & \\
\hline 67. Saluran Keliling & 9 & 35,50 \\
\hline 68. Rabat Beton $(1: 2: 3)$ & 22 & 35 \\
\hline 69. Bak Kontrol & 1 & 68 \\
\hline 70. Septictank & 4 & 67,69 \\
\hline 71. Resapan & 1 & $61,62,70$ \\
\hline
\end{tabular}

(Sumber : PT At-Taqwa Sejahtera, 2017)

b. Jumlah tenaga kerja dan jam kerja.

Pada kegiatan proyek jumlah tenaga kerja sebanyak 12 orang per 1 (satu) unit rumah. Pada jam kerja setiap harinya dilakukan selama 8 jam dengan 8 jam waktu efektif dan 1 jam istirahat. Jam kerja dimulai pukul 08.00 WIB - 17.00 WIB dan waktu istirahat pukul 12.00 WIB - 13.00 WIB. Hari kerja dilakukan setiap hari yaitu hari Senin sampai hari Minggu.

\section{Pengolahan data}

a. Rekap hasil perhitungan waktu proyek dan biaya proyek

Rekap hasil perhitungan waktu proyek dan biaya proyek berdasarkan

perhitungan titik proyek dipercepat (TPD) menggunakan slope biaya, dapat dilihat pada tabel berikut.

Tabel 2. Rekap hasil perhitungan waktu proyek dan biaya proyek

\begin{tabular}{|c|c|cc|}
\hline No & $\begin{array}{c}\text { Waktu } \\
\text { Proyek }\end{array}$ & \multicolumn{2}{|c|}{ Biaya Proyek } \\
\hline 1 & 164 & Rp & $400.907 .306,25$ \\
\hline 2 & 163 & Rp & $401.906 .261,25$ \\
\hline 3 & 163 & Rp & $401.072 .912,25$ \\
\hline 4 & 160 & Rp & $402.310 .654,25$ \\
\hline 5 & 160 & Rp & $401.745 .102,25$ \\
\hline
\end{tabular}




\begin{tabular}{|c|c|cc|}
6 & 160 & $\mathrm{Rp}$ & $400.907 .306,25$ \\
\hline 7 & 158 & $\mathrm{Rp}$ & $404.395 .502,25$ \\
\hline 8 & 152 & $\mathrm{Rp}$ & $401.345 .002,25$ \\
\hline 9 & 151 & $\mathrm{Rp}$ & $401.795 .402,25$ \\
\hline 10 & 147 & $\mathrm{Rp}$ & $408.407 .114,25$ \\
\hline 11 & 147 & $\mathrm{Rp}$ & $417.315 .909,25$ \\
\hline
\end{tabular}

Dari hasil perhitungan titik proyek dipercepat (TPD) dilanjutkan menghitung nilai probabilitas pecepatan, didapatkan $63 \%$ berdasarkan tabel distribusi normal kumulatif $\mathrm{z}$. b. Hasil rekap simulasi monte carlo.

Berikut merupakan hasil rekap dari hasil simulasi monte carlo setelah dketahui nilai probabilitas untuk masing-masing durasi, dapat dilihat pada tabel berikut.

Tabel 3. Probabilitas Keberhasilan dengan Simulasi Monte Carlo

\begin{tabular}{|c|c|c|}
\hline $\begin{array}{c}\text { Durasi } \\
\text { Pekerjaan } \\
\text { (Hari) }\end{array}$ & Frekuensi & $\begin{array}{c}\text { Probabilitas } \\
(\%)\end{array}$ \\
\hline 147 & 0 & 100 \\
\hline 148 & 2 & 92 \\
\hline 149 & 3 & 88 \\
\hline 150 & 1 & 96 \\
\hline 151 & 4 & 85 \\
\hline 152 & 3 & 88 \\
\hline 153 & 0 & 100 \\
\hline 154 & 0 & 100 \\
\hline 155 & 2 & 92 \\
\hline 156 & 2 & 92 \\
\hline 157 & 3 & 88 \\
\hline 158 & 1 & 96 \\
\hline 159 & 0 & 100 \\
\hline 160 & 0 & 100 \\
\hline 161 & 1 & 96 \\
\hline 162 & 0 & 100 \\
\hline
\end{tabular}

Tabel 3. (Lanjutan)

\begin{tabular}{|c|c|c|}
\hline $\begin{array}{c}\text { Durasi } \\
\text { Pekerjaan } \\
\text { (Hari) }\end{array}$ & Frekuensi & $\begin{array}{c}\text { Probabilitas } \\
(\boldsymbol{\%})\end{array}$ \\
\hline 163 & 3 & 88 \\
\hline 164 & 1 & 96 \\
\hline
\end{tabular}

- Probabilitas Simulasi Monte Carlo

Probabilitas rata-rata $=\frac{\text { Probabilitas Durasi Pekerjaan }}{\text { Banyaknya Populasi Probabilitas }}$

$$
\begin{aligned}
& =\frac{(100 \% X 6)+(92 \% X 3)+(88 \% X 4)+(96 \% X 4)+85 \%}{18} \\
& =94 \%
\end{aligned}
$$

- Percepatan Waktu Simulasi Monte Carlo

Percepatan rata-rata $=\frac{\text { Total Durasi Durasi Pekerjaan }}{\text { Banyaknya Pekerjaan }}$ 


$$
\begin{aligned}
& =\frac{147+148+149+150+151+152+153+15 \ldots+164}{18} \\
& =156 \mathrm{hari}
\end{aligned}
$$

- Biaya Percepatan Waktu Simulasi Monte Carlo

Biaya = biaya waktu normal + biaya waktu percepatan

$$
\begin{aligned}
& =\operatorname{Rp} 400.907 .306,25+\operatorname{Rp} 1.403 .348 \\
& =\operatorname{Rp} 402.310 .654,25
\end{aligned}
$$

c. Analisis Hasil

Berdasarkan hasil pengolahan data menggunakan titik proyek dipercepat (TPD) didapatkan waktu penyelesaian proyek selama 147 hari, dengan total slope biaya sebesar Rp 417.315.909,25. Kemudian pada perhitungan Program Evaluation Review and Technique (PERT), probabilitas yang dihasilkan untuk percepatan selama 147 hari sebesar $63 \%$, dengan distribusi normal kumulatif $\mathrm{Z}$. Sedangkan pengolahan data menggunakan simulasi Monte carlo didapatkan hasil percepatan waktu rata-rata selama 156 hari, dengan biaya percepatan sebesar Rp

\section{KESIMPULAN}

Berdasarkan hasil analisis melalui penerapan simulasi monte carlo dan metode Program Evaluation Review and Technique (PERT) didapatkan kesimpulan sebagai berikut:

a. Pembangunan proyek memiliki jadwal penyelesaian selama 152 hari namun terjadi keterlambatan, hal tersebut diakibatkan terlambatnya pasokan bahan baku pada tahapan kontruksi beton yang mengakibatkan mundurnya penyelesaian proyek selama 12 hari. akibat keterlambatan tersebut terdapat biaya penalty yang harus dibayarkan sebesar Rp 20.045.365.

b. Penyelesaiaan proyek dapat dipercepat pada Titik Proyek Dipercepat (TPD) menjadi 147 hari dengan biaya sebesar Rp 417.315.909,25, sedangkan menggunakan penerapan simulasi monte carlo waktu percepatan selama
402.310.654,25 dan probabilitas rataratanya sebesar $94 \%$.

Berdasarkan perbedaan besaran nilai probabilitas dapat dikatakan kontraktor bisa menggunakan metode simulasi monte carlo dikarenakan nilai percepatan dengan nilai probabilitas keyakinan penyelesaian proyek yang mencapai $94 \%$ serta biaya yang lebih sedikit. Hal ini lebih mendekati pada situasi nyatanya. Simulasi monte carlo juga menggunakan variabel yang tidak terduga, hal tersebut bisa menggambarkan beberapa factor yang biasanya timbul pada pengerjaan suatu proyek.

156 hari dengan biaya sebesar Rp 402.310.654,25.

c. Hasil presentase (\%) probabilitas percepatan yang dilakukan menggunakan metode Program Evaluation Review and Technique (PERT) memiliki tingkat keyakinan sebesar 63\%. Sedangkan, hasil penerapan simulasi monte carlo berdasarkan hasil rata-ratanya memiliki tingkat keyakinan penyelesaian proyek sebesar $94 \%$. 


\section{DAFTAR PUSTAKA}

Arifin, M., 2009, Simulasi Sistem Industri, Graha Ilmu, Yogyakarta.

Aulabih, R., Unas, E, S., \& Negara P, K., 2016, Penerapan Metode Monte Carlo pada Penjadwalan Proyek Gedung Dinas Sosial Kota Blitar.

Dannyanti, E., 2010, Optimalisasi Pelaksaan Proyek dengan Metode PERT dan CPM, Skripsi Fakultas Ekonomi Universitas Diponegoro.

Fadjar, A., 2008, Aplikasi Simulasi Monte Carlo dalam Estimasi Biaya Proyek, Jurnal SMARTek, 6(4), pp. 222-227.

Hartono, W., \& Laksito, B., 2006, Simulasi Fase Procurement pada Pembangunan Pabrik Amonia dan Urea Kujang 1-B, Media Teknik Sipil. Januari 2006.

Handoko, T, H., 1999, Manajemen Proyek Edisi 2, Yogyakarta: BPFE.

Heizer, J., \& Render, B., 2005, Operation Management, 9th book 1, Salemba Empat, Jakarta.

Kerzner, K., 2006, Project Management: A System to Planning, Scheduling and Controlling, Ninth Edition, John Wiley \& Sons.

Kho, B., 2016, Segitiga Manajemen Proyek dan Tahapan Manajemen Proyek, http://www.ilmumanajemenindustri.com , diakses pada 8 Juni 2017.

Law, M, A., \& Kelton, D, W., 2000, Simulation Modeling and Analysis, The McGraw-Hill Companies, Inc, Singapore.
Misrali et al., 2015, Evaluasi Penjadwalan Waktu dan Biaya pada Proyek Pembangunan Gedung Kelas di Fakultas Ekonomi Universitas Jember dengan Metode Pert, Artikel Ilmiah Mahasiswa 2015.

Project Management Institute, 2000, A Guide to the Project Management Body of Knowledge (PMBOK Guide) 2000 Edition, Newton Square, PA 190733299 USA.

Raharja, I., 2014, Analisa Penjadwalan Proyek dengan Metode PERT di PT Hasana Damai Putra Yogyakarta pada Proyek Perumahan Tirta Sani, Jurnal BENTANG, 2(1).

Santosa, B., 2009, Manajemen Proyek Konsep \& Implementasi, Graha Ilmu, Yogyakarta.

Soeharto, I., 2002, Studi Kelayakan Proyek Industri, Penerbit Erlangga, Jakarta.

Subagya, 2000, Analisis Manajemen Proyekjilid 2, Graha Pena, Bekasi.

Taha, H, A., 1997, Operation Research An Introduction (6th ed), Upper Saddle River, New Jersey: Prentice-Hall, Inc.

Tersine, J, R., 1994, Principles of Inventory and Materials Management, PrenticeHall International, Inc, New Jersey 07632. 